\title{
INTEGRATING ANALYTIC HIERARCHY PROCESS (AHP) AND GEOGRAPHICAL INFORMATION SYSTEMS (GIS) FOR PRIORITISING AND PLANNING CONSERVATION CHOICES IN WALES
}

\author{
Marcello Di Bonito and John Clarkson* \\ School of Animal, Rural and Environmental Sciences \\ Nottingham Trent University \\ Nottingham, UK \\ E-mail: $\underline{\text { marcello.dibonito@ntu.ac.uk }}$ \\ Michelle L. Wienhold \\ School of Forensic and Investigative Sciences, \\ University of Central Lancashire, \\ Preston, UK \\ E-mail: $\underline{\text { mlwienhold@uclan.ac.uk }}$ \\ Leandro Pecchia* \\ Electrical Systems and Optics Research Division, \\ Faculty of Engineering, \\ University of Nottingham, \\ Nottingham, UK \\ Email: leandro.pecchia@nottingham.ac.uk
}

\begin{abstract}
This paper presents an integrated geographical ('spatially explicit') and multivariate approach to address complex planning situations for wildlife conservation and assist decision-making. Geographic Information System (GIS) and Analytic Hierarchy Process (AHP) were combined and applied to ecological and decisional variables and their association with known occurrences of barn owls (Tyto alba) in an area of Wales (UK). The output is presented as geographic distribution maps showing the environmental conditions that are potentially suitable for the species and 'heat maps' for the benefit of decision-making process. The application of the AHP allowed a detailed understanding of how the relative importance of each variable was elicited. This is paramount to define a fully understandable framework of decision-making that can be easily readapted to different geographical scenarios and with different species.
\end{abstract}

Keywords: barn owl, geographic information system, analytic hierarchy process.

\section{Introduction}

Biodiversity is considered critical to the survival of human beings (MA, 2005). Yet it may be undergoing a period of mass extinction for the sixth time in the history of life on this planet, which is a result of human activities (Barnofsky et al., 2011; Crutzen, 2002). In 1992, nations gathered in Rio de Janeiro to sign the Convention on Biological Diversity, an agreement to halt the decline in biodiversity and in 2002 set a target date of 2010 to achieve that aim. Significant causes for the decline include habitat loss, land use change, fragmentation and climate change (MA, 2005; Opdam \& Wascher, 2004) and by 2010

\footnotetext{
${ }^{*}$ Corresponding author
} 
declines in biodiversity were still in evidence (Butchart et al.., 2010), requiring a new Strategic Plan for Biodiversity 2011-2020 to be agreed at the $10^{\text {th }}$ Conference of the Parties to the Convention on Biological Diversity (CBD) in Nagoya (Diaz et al., 2012).

There are many reasons for the failure to achieve the 2010 target, ranging from global geo-politics (Spierenburg, 2012) to lack of funding (Margules \& Pressey, 2000) but it has become increasingly apparent that, in order to attain the new target, to halt biodiversity loss by 2020 , a more effective and integrated approach is required to the conservation of biodiversity, with delivery more closely linked to strategic planning (Diaz et al., 2012). Two of the most significant challenges for delivery of biodiversity conservation are the inherent uncertainties over the most cost-effective approach (Sutherland et al., 2009) and the emerging issue of scale mis-match (Cumming et al., 2006; du Toit, 2010).

The problem of working at different scales for planning and delivery is especially important when considering the need to move away from a protected areas approach to conservation to one in the wider ecological landscape (eg Lawton et al., 2010) and when delivery resources are limited (Guerrero et al., 2012). Mindful of the current (global) economic climate, the estimated sums of money required to deliver the 'Aichi' targets - several hundreds of billions of US dollars to address the drivers of biodiversity loss and ecosystem restoration, for instance (Sukhdev et al., 2012) - may be unattainable in the relatively short term, heightening the need for a planned and strategic approach to the use of scarce resources.

Such an approach needs encompass not just biological considerations but social and economic ones also (Guerrero et al., 2012), and conservationists are beginning to incorporate hitherto excluded but critical factors such as the willingness of land managers to be engaged (Knight et al., 2011) in their approaches to mapping conservation opportunities. That the land managers who will be responsible for delivery and maintenance of biodiversity action outside of protected areas may be more inclined to be engaged more with species actions rather than habitats, and at the same time face potentially significant financial challenges themselves (Mir and Dick,2012) makes this consideration more vital.

These types of complex analyses call for a multi-criteria approach and require a 'spatially explicit' representation of the results. Various multi-criteria methodologies are available for this purpose (see for example the work by Funtowicz, Munda and Paruccini, 1990 and Munda, 2004), the choice of method to adopt depends on the nature of the issues, and the approach considered. In particular, as suggested more recently by various authors (e.g., Şener et al., 2010; Kara and Doratli, 2012; Fusco Girard, Cerreta \& De Toro, 2012), the Analytic Hierarchy Process (AHP) has been successfully integrated with the GIS tools to allow decision-making to go beyond the simple overlay of different themes through pairwise comparisons of the criterion established for each hierarchical level. The AHP seems to stand out from the mass of multi-criteria approaches for its potentials in decision making applications and has been applied to several complex decision-making problems (Saaty and Zoffer, 2011), especially in public decision-making (Liberatore and Nydick, 2008) but also for budget allocation (Tarimcilar and Khaksari, 1991) and very practical applications, such as medical device purchasing (van Til, et al., 2008).

On the other hand, 'spatial' representations are nowadays commonly performed in a Geographic Information System (GIS) environment, and the recent literature is constellated by examples of GIS applications in many fields (see for example Campagna, 2006; Wise \& Bettinger, 2008; Imam \& Kushwaha, 2013). The integration of multi-criteria methodologies with GIS tools is not uncommon and has been auspicated and tested already in the past by several authors with more or less success (e.g., Carver, 1991; Chen, Blong, and Jacobson, 2001; Malczewski, 1999 and 2004).

For this reason the present study aims to perform an integration of AHP with GIS tools to manage wildlife conservation issues in their entirety, using the Barn Owl (Tyto alba) distribution in Wales (UK) as a case study (see Materials and methods for more details).

\section{Materials and methods}

\subsection{Study area}

The region of study encompasses the Biodiversity Information Service (BIS) area which is one of the four Environmental Local Record Centres that seamlessly cover Wales and includes Brecon Beacons National 
Park, Brecknockshire, Radnorshire and Montgomeryshire (see Figure 1). It is one of 70 records centres of its kind to house biodiveristy information in the United Kingdom (BIS 2008). With permission from BIS and Brecon Beacons National Park, a database of all barn owl observation records was provided for this analysis.

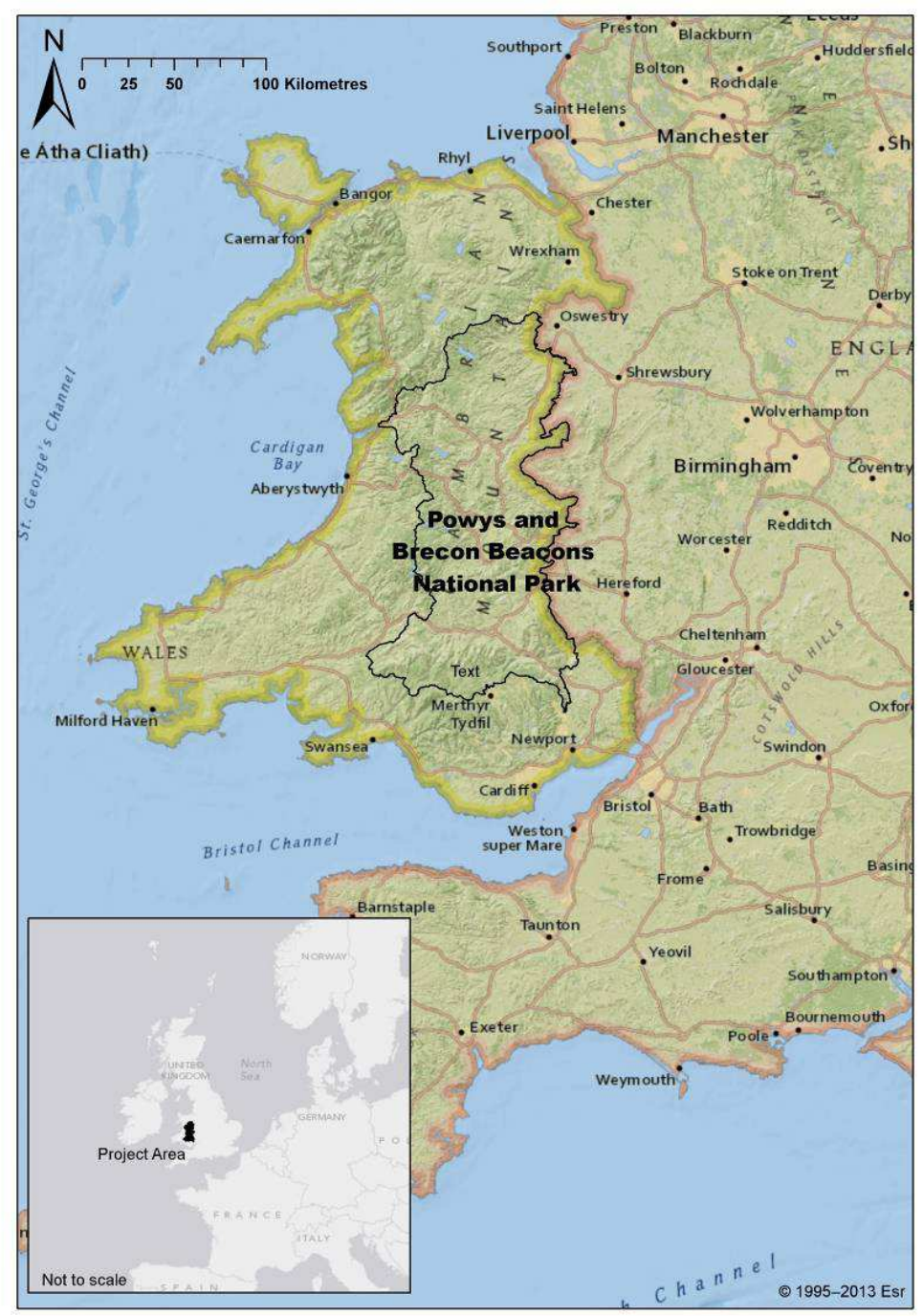

Figure 1. Study area.

\subsection{Barn Owl}

The species used for this study is the barn owl (Tyto alba). This species is of conservation concern and is currently dependent upon the actions of land managers. Barn owls are found across the world but have suffered a significant decline in numbers, especially across Europe, over the latter part of the last century which (Batten, et al., 1990; BirdLife International, 2004). The decline has mainly been due to loss of foraging habitat and possibly both the loss of nesting sites and the impacts of ingestion of rodenticides (Dadam et al., 2011). These are factors closely related to the economy of the enterprise which maintains the land use which barn owls primarily occupy: agriculture. In the UK, over the last couple of decades considerable effort has been expended on increasing the numbers of barn owls by a variety of means, including captive breeding and release programmes and habitat improvements. Limiting factors to 
obtaining a sustained and sustainable increase in the numbers of barn owls may include inadequate amounts and quality of foraging habitat, (and related to that) numbers of prey, loss of suitable nesting sites (Taylor, 1994), continued use of rodenticides, the proximity of roads (Ramsden, undated) and unfavourable weather patterns (Dadam et al., 2011). Other variables for consideration include the propensity for landowners to accept or not the presence of barn owls on their land, the impacts upon the profit-margins of the (generally) farms upon which conservation programmes are undertaken and the achievability of that action, the proximity and presence of other barn owls and direct competitors and the availability of funds with which to enable the necessary changes to management of the land (Askew, Searle, \& Moore, 2007). All of these variables vary in intensity across the landscape, and may vary in their relative importance similarly. In order to best facilitate the strategic targeting of limited resources (money, expertise and time) conservationists may benefit from a simple but robust spatially interactive method of taking account of and weighting those variables in order to identify the priority areas for action (Margules \& Pressey, 2000; Naidoo \& Ricketts, 2006).

\subsection{GIS methodology}

All the input data for the GIS analysis were resampled to a 30 metres resolution for the study. All of the original species and raster data were created in ESRI's ArcGIS 10 software (ESRI, 2013). Datasets included:

- Digital Elevation Model (DEM) (USGS): This data was downloaded from United States Geological Survey (USGS) SRTM (USGS, 2013) at a 30 meter resolution.

- Aspect (Derived from USGS): This dataset was produced with ArcGIS 10's Spatial Analyst extension using the DEM as input.

- Major roads (from Ordnance Survey Strategi - OS, 2013).

- Historic Barn Owl locational data (from BIS).

\subsection{AHP methodology}

Several factors considered relevant to maintain the number of owls were identified and discussed with three experts with different background and a hierarchy of factors was developed (Figure 2).

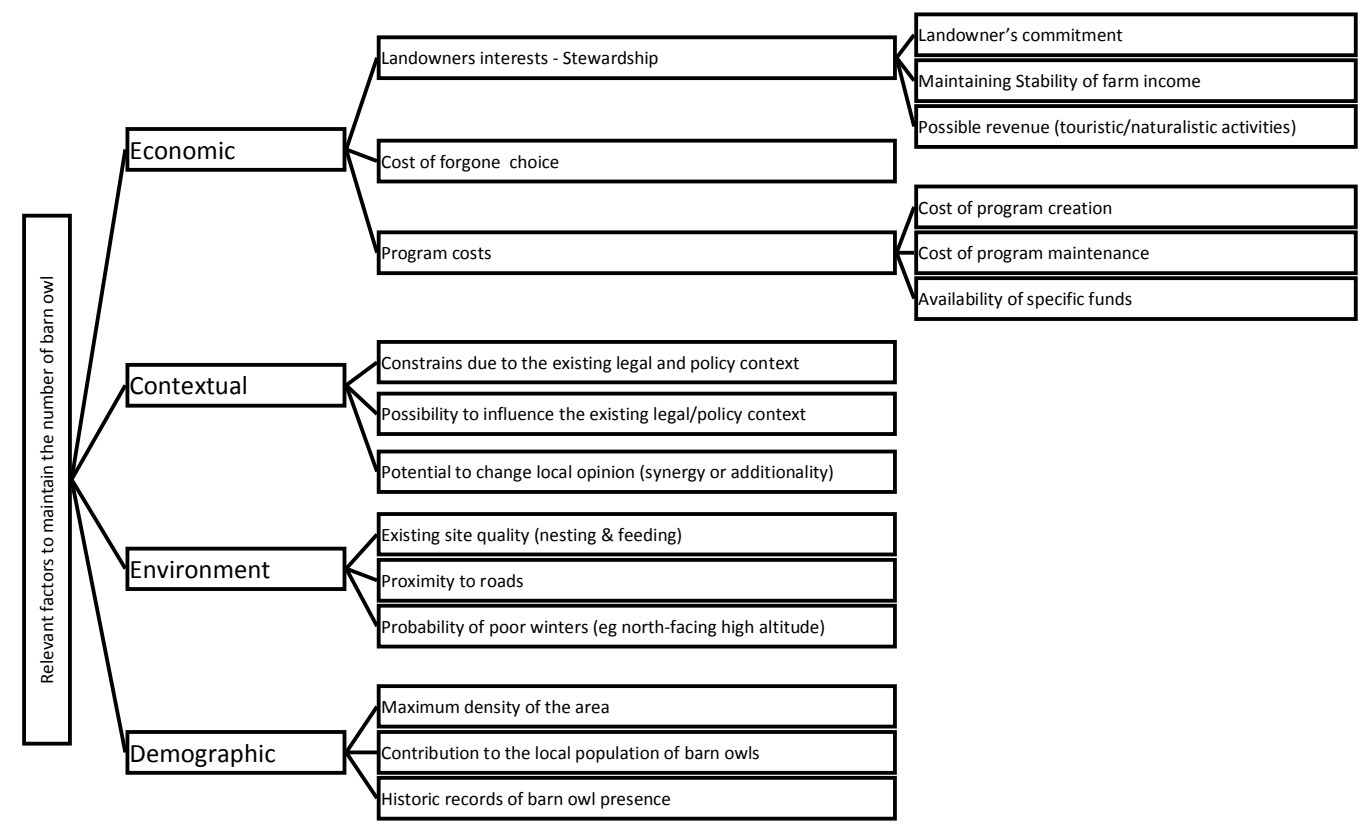

Figure 2: hierarchy of factors that affect the number of owls. 
According to this hierarchy, questionnaires were developed to estimate the priority of each factor and factor category (Figure 3). Since in each node of the hierarchy there were not more than three factors, only 5 judgments were used (Pecchia et al., 2013). These were then quantified using the Saaty natural scale (Saaty, 1994).

\begin{tabular}{|r|c|c|c|c|c|c|r|r|}
\hline Landowner's commitment & is & $\begin{array}{l}\text { much } \\
\text { more }\end{array}$ & more & equally & less & $\begin{array}{r}\text { much } \\
\text { less }\end{array}$ & $\begin{array}{r}\text { Important } \\
\text { than }\end{array}$ & Maintaining Stability of farm income \\
\hline Maintaining Stability of farm income & is & $\begin{array}{l}\text { much } \\
\text { more }\end{array}$ & more & equally & less & $\begin{array}{r}\text { much } \\
\text { less }\end{array}$ & $\begin{array}{r}\text { Important } \\
\text { than }\end{array}$ & Possible revenue (touristic/naturalistic activities) \\
\hline Possible revenue (touristic/naturalistic activities) & is & $\begin{array}{l}\text { much } \\
\text { more }\end{array}$ & more & equally & less & $\begin{array}{r}\text { much } \\
\text { less }\end{array}$ & $\begin{array}{r}\text { Important } \\
\text { than }\end{array}$ & Landowner's commitment \\
\hline
\end{tabular}

Figure 3: questionnaire layout.

Five experts with different background answered to the questionnaire: an etiologist, an ecologist, an agriculture consultant, a spatial analyst and an environmental scientist. A consistency ratio (CR) less than 0.1 was adopted. Inconsistencies were discussed with respondents individually. Finally, consensus was achieved among respondents by discussing the achieved results.

\subsection{GIS-AHP integration}

The scores obtained from the AHP method were linked to the variables to be used for the spatial representation. The relative importances of the six Environmental and Demographic factors were used to weight the GIS database variables. Since "maximum density of owls in the area" was a reserved information, the remaining five factors were utilized after being normalized to one, according to the distributive mode.

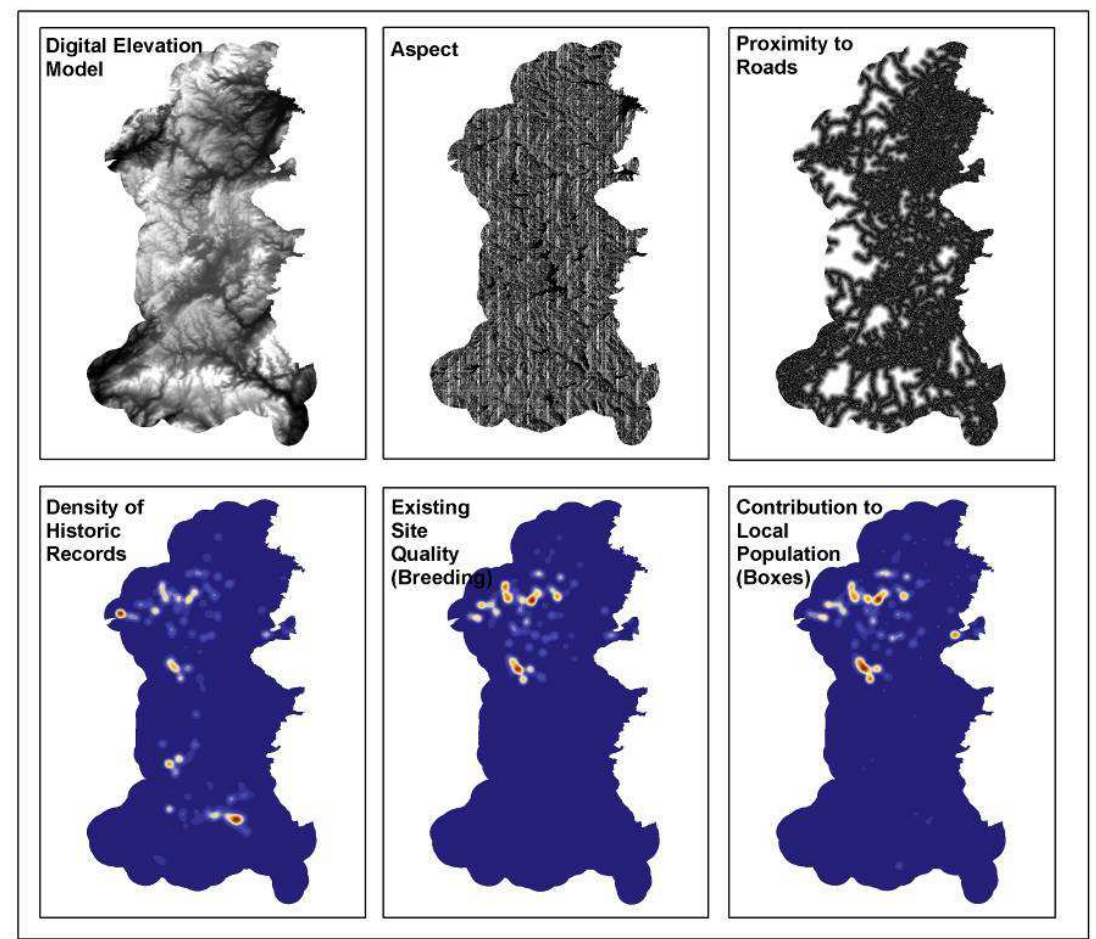

Figure 4. Environmental variables considered for the AHP weighting and GIS calculation. 
Each variable available as a raster dataset was weighed by the AHP score and a summative map was produced by using the Weighted Sum tool available in the Spatial analyst toolbox of ArcGIS 10. The tool weighs and adds multiple raster to create a new output. The resulting map was represented with a chromatic scale associated with the level of importance of the sum of the variables. The graphic representation used also exclusion zones for those areas that are ecologically not suitable for the species considered. In particular, elevation higher than $700 \mathrm{~m}$ above sea level (asl) which are represented by the colour white in the map. The variables included in the GIS calculation are shown in Figure 4.

\section{Results and discussion}

The relative importances of all the categories of factors are reported in Table 1.

Table 1. Relative importance of categories of factors included in the questionnaire $(\mathrm{CR}<0.1)$.

\begin{tabular}{|l|c|}
\hline Factor & Relative importance \\
\hline Economic & 0.28 \\
\hline Contextual & 0.23 \\
\hline Environment & 0.28 \\
\hline Demographic & 0.21 \\
\hline
\end{tabular}

The local and the global relative importances of each factors are reported in Table 2.

Table 2. Local and Global weights of all the factors used in the questionnaire $(\mathrm{CR}<.01)$.

\begin{tabular}{|l|c|c|}
\hline Economic & Local Weight & Global Weight \\
\hline Landowners interests - Stewardship & 0.37 & 0.10 \\
\hline Cost of forgone choice & 0.37 & 0.09 \\
\hline Program costs & 0.26 & 0.09 \\
\hline Contextual & & \\
\hline Constrains due to the existing legal and policy context & 0.31 & 0.07 \\
\hline Possibility to influence the existing legal/policy context & 0.32 & 0.07 \\
\hline Potential to change local opinion (synergy or additionality) & 0.36 & 0.08 \\
\hline Environment & & \\
\hline Existing site quality (nesting \& feeding) & 0.35 & 0.10 \\
\hline Proximity to roads & 0.38 & 0.11 \\
\hline Probability of poor winters (e.g., north-facing, high altitude) & 0.27 & 0.08 \\
\hline Demographic & & \\
\hline Maximum density of the area & 0.45 & 0.09 \\
\hline Contribution to the local population of barn owls & 0.32 & 0.07 \\
\hline Historic records of barn owl presence & 0.23 & 0.05 \\
\hline
\end{tabular}

The AHP method allowed the quantification of the relative importance of the factors that, according to the experience of the respondents, affect the number of owls in the region. This is particularly important to facilitate the discussion with stakeholders that are responsible for the development of future regional plans for the maintenance of species at risk. 
In particular, the environmental and demographic factors that, according to respondents experience, affect the number of owl in the identified region, were weighted and, once normalized using the distributive mode, utilized to weight the corresponding information available in the GIS database. This allowed the development a GIS approach that was able to produce outputs such as the map shown in this paper (see Figure 5). This can be very valuable because allows the matching and/or comparing of 'aprioristic' knowledge on selected species with local environmental and demographic information. This can be particularly valuable to develop more effective local plans using general and local knowledge.

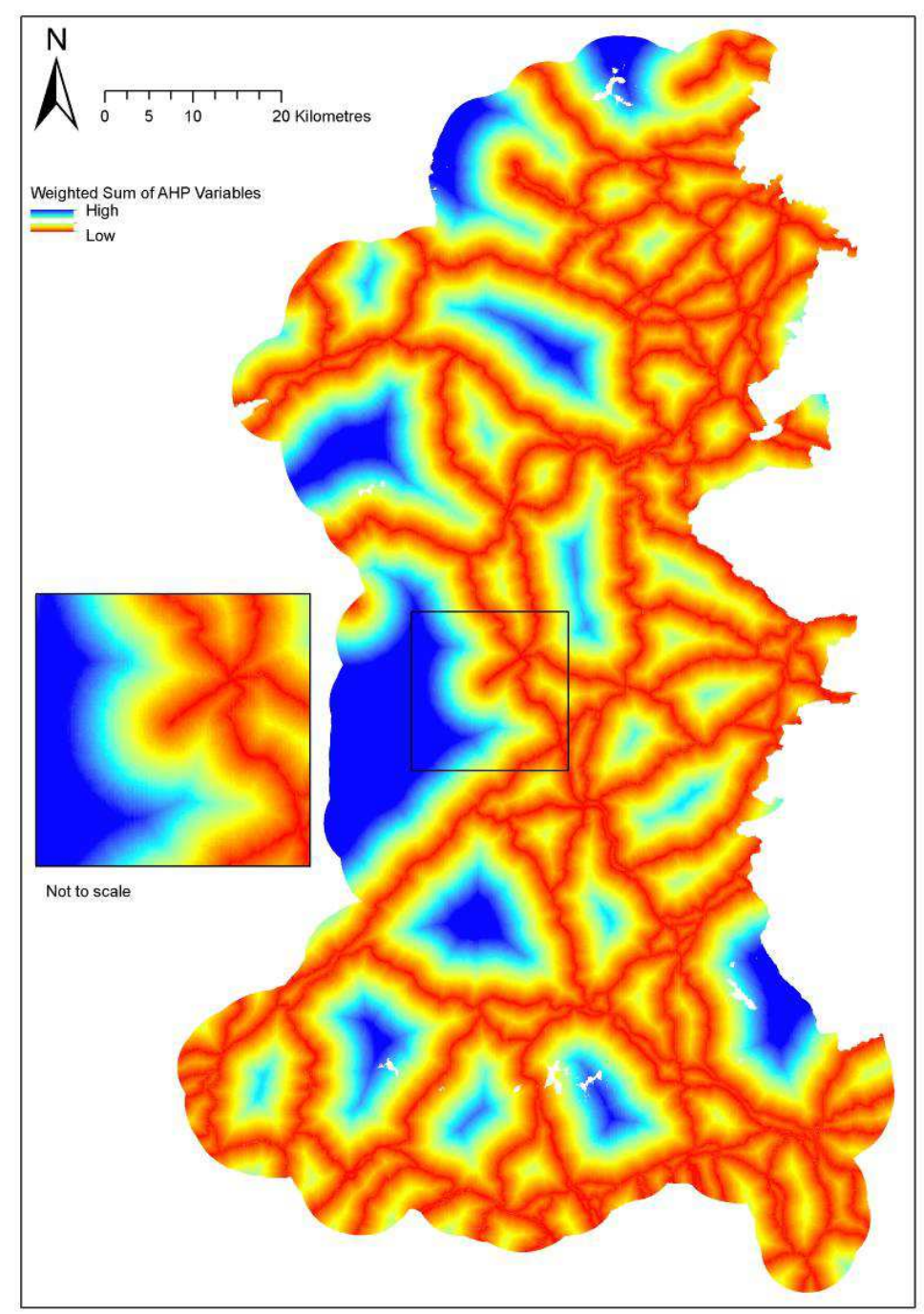

Figure 5. Weighed map of experts' priorities for Barn Owls conservation in the study area.

Figure 5 presents the GIS output of the combined AHP/GIS approaches for the environmental variables considered (see fig. 4 too). The map highlights the relative greater weight of the distance to road as a variable for the questionnaire respondents. The sum of the weighed variables shows how areas to focus on could be easily marked by considering this simple analysis. It is recognised that the method needs further development in order to avoid variables (ecological or specialist) misinterpretation (e.g., the apparent 
inverted importance of elevation). However, the method does allow for several iterations and localised outputs to be produced, so to avoid either false double counting and/or expert corrections.

With limited resources available for conservation actions (Margules \& Pressey, 2000) and the timescale for effective delivery urgent (MA, 2005) it is vital that a cost-effective strategic approach is adopted. It is increasingly recognised that future conservation efforts need to be more carefully considered, and that a raft of delivery mechanisms are required. The provision of species/habitat suitability maps is important but equally importantly many species and habitats are potentially reliant upon the interest, engagement and capabilities of private land owners and managers. There is an overwhelming need, therefore, to embrace an understanding of the costs and benefits incurred by (Naidoo \& Ricketts, 2006) and the willingness to be involved (Knight et al., 2011) of the land-owners and managers. Further complexity is added when there is a need to consider the potentially intrinsically different values that conservationists and land-managers may place upon biodiversity and the need for conservation. Previously much of this information would take considerable time and resources to acquire in a meaningful way. The AHP approach, requiring as it does a relatively quick but robust method of capturing the different values of the different stakeholders, enables a 'values-neutralising' consideration of the essentially important variables which may define the eventual success or failure of a process of conservation actions. Interestingly, the sole engagement with the AHP process and the construction and completion of the questionnaire for this study, did lead to a deeper understanding of the potentially different values expressed by the different stakeholders. This will inevitably lead to more sympathetic and pre-emptive consideration of what may at first not appear to be significantly limiting factors in the delivery of conservation actions. Furthermore, a significant advantage over a purely biological suitability mapping approach is that the importance of those non-biological considerations may be brought to the fore when delivery is hampered by them. As a result, factors such as the (perceived or actual) difficulty of accessing support funding or resources, or indeed, the actual in/adequacy of those support mechanisms may be highlighted, allowing the consideration of hypothetical changes that may be sufficient to overcome those blockages. This would enable resources to be more effectively targeted at the most important blockages at that time, such as policy change.

\section{Conclusions}

The application of the AHP method makes possible to produce weights for the considered criteria, which can then be combined within a GIS environment to produce 'priority maps' that can be used to guide efforts to focus conservation and reintroduction for the species considered.

The method is at its early stages of development and needs further work, particularly its synergy with the GIS environment, but shows potential to constitute a useful tool for decision making in conservation issues. In particular, the AHP method has the potential to facilitate the discussion with stakeholders for the definition of new and more effective environmental plans, adapting 'aprioristic' knowledge to specific local characteristic. This can be particularly valuable to develop local, specific plans. Furthermore, once fully developed, the same method can be easily applied to different species and/or in different regions.

Delivery of conservation actions is going to be increasingly reliant on partnership and trust between all of the most important stakeholders and either the removal of conflicting goals or the enhanced synergy of complementary goals. A properly undertaken AHP process may enable this to be achieved.

\section{REFERENCES}

Askew, N.P., Searle, J.B. \& Moore, N.P. (2007). Agri-environment schemes and foraging of barn owls Tyto alba, Agriculture, Ecosystems and Environment 118: 109-114.

Barnosky, A.D., Matzke, N., Tomiya, S., Wogan, G.O.U., Swartz, B., Quental, T.B, Marshall, C., McGuire, J.L., Lindsey, E.L., Maguire, K.C., Mersey, B. \& Ferrer, E.A. (2011). Has the Earth's sixth mass extinction already arrived? Nature 471: 57. 
Batten, L.A., Biby, C.J. Clement, P., Elliott, G.D. \& Porter, R.F., (Eds), (1990). Red Data Birds in Britain, T\&AD Poyser: London.

BirdLife International (2004). Birds in Europe population estimates, trends and conservation status. Cambridge, UK: BirdLife International (BirdLife Conservation Series No. 12).

Butchart et al., 2010 Global Biodiversity Declines Continue Science 328: 1164-1168

Campagna, M. (2006). GIS for sustainable development. Crc Press.

Carver, S.J. (1991). Integrating multi-criteria evaluation with geographical information systems, International Journal of Geographical Information Systems, 5, 321-339.

Chen, K., Blong, R., \& Jacobson, C. (2001). MCE-RISK: integrating multicriteria evaluation and GIS for risk decision-making in natural hazards, Environmental Modelling and Software, 16,387-397.

Crutzen, P.J., 2002, Geology of mankind: Nature, v. 415, p. 23

Cumming, G. S., Cumming, D. H. M., \& Redman, C. L. 2006. Scale Mismatches In Social-Ecological Systems: Causes, Consequences, And Solutions. Ecology and Society 11(1): 14.

Dadam, D., Barimore, C.J., Shawyer, C.R. \& Leech, D.I. (2011). The BTO Barn Owl Monitoring Programme: Final Report 2000-2009, BTO Research Report 577, BTO Thetford

Díaz, S., Reyers, B., Bergendorff, T., Brussaard, L., Cooper, D., Cramer, W., Duraiappah, A., Elmqvist, T., Faith, D.P, Fonseca, G., Hammond, T., Jackson, L.E, Krug, C., Larigauderie, A., Leadley, P.W., Le Prestre, P., Lonsdale, M., Lovejoy, T.E, Mace, G.M., Matsuda, H., Mooney, H.A., PrieurRichard, A-H., Pulleman, M., Rosa, E.A., Scholes, R.J., Spehn, E., Turner II, B.L., Williams, M.J., Yahara, T. 2012 Biodiversity and ecosystems for a planet under pressure Transition to sustainability: Interconnected challenges and solutions Rio+20 Policy Brief \#4

du Toit, J. T. (2010). Considerations of scale in biodiversity conservation Animal Conservation 13: 229236.

Funtowicz, S., Munda, G., and Paruccini, M. (1990). The aggregation of environmental data using multicriteria methods. Environmentrics, 1:353-368.

Fusco Girard, L., Cerreta, M., \& De Toro, P. (2012). Analytic hierarchy process (AHP) and Geographic Information systems (GIS): an integrated spatial assessment for planning strategic choices. International Journal of the Analytic Hierarchy Process, 4(1), 4-26.

Guerrero et al., 2012 Scale Mismatches, Conservation Planning, And The Value Of Social-Network Analyses. Conservation Biology, Volume 27, No. 1, 35-44

Imam, E., \& Kushwaha, S.P.S. (2013). Habitat suitability modelling for Gaur (Bos gaurus) using multiple logistic regression, remote sensing and GIS.Journal of Applied Animal Research, (ahead-of-print), 111.

Kara, C., and Doratli, N., (2012). Application of GIS/AHP in siting sanitary landfill: a case study in Northern Cyprus. Waste Management \& Research, 30(9), 966-980.

Knight, A.T., Sarkar, S., Smith,R.J., Strange, N. \& Wilson, K. A. 2011 Engage The Hodgepodge: Management Factors Are Essential When Prioritizing Areas For Restoration And Conservation Action. Diversity and Distributions, 17, 1234-1238

Liberatore, M.J., and Nydick, R.L., (2008). The analytic hierarchy process in medical and health care decision making: A literature review, European Journal of Operational Research, vol. 189, 194-207.

MA. 2005. Ecosystems and human well-being: Synthesis. Washington, D.C.: Island.

Malczewski, J. (1999), GIS and multicriteria decision analysis, New York, Wiley.

Malczewski, J. (2004). GIS-based land-use suitability analysis: a critical overview. Progress in Planning, 62,3-65.

Margules, C.R., \& Pressey, R.L.(2000). Systematic conservation planning. Nature, 405: 243-253. 
Mir, D.F. \& Dick, K. (2012). Conservation Approaches to Protecting Critical Habitats and Species on Private Property Natural Areas Journal, 32(2):190-198.

Munda, G. (2004). Social multi-criteria evaluation: Methodological foundations and operational consequences. European Journal of Operational Research ,158:662-677.

Naidoo R, \& Ricketts, T.H. (2006). Mapping the economic costs and benefits of conservation, PLoS Biol 4(11): e360.

Opdam, P. \& Wascher, D. (2004). Climate change meets habitat fragmentation: linking landscape and biogeographical scale levels in research and conservation Biological Conservation 117: 285-297

Pecchia, L., Martin, J., Ragozzino, A., Vanzanella, C., Scognamiglio, A., Mirarchi, L., and Morgan, S. (2013). User needs elicitation via analytic hierarchy process (AHP). A case study on a CT scanner, BMC Medical Informatics and Decision Making, 3(1):2, DOI:10.1186/1472-6947-13-2.

Ramsden, R.J., undated. Barn Owls and Major Roads. The Barn Owl Trust, Ashburton, Devon

Saaty, T.L. (1994). Fundamentals of decision making and priority theory with the analytic hierarchy process, $1^{\text {st }}$ ed. Pittsburgh, PA: RWS Publications.

Saaty, T.L., and Zoffer, H.J. (2011). Negotiating the Israeli-Palestinian Controversy from a New Perspective, International Journal of Information Technology \& Decision Making, vol. 10, 5-64.

Şener, Ş., Şener, E., Nas, B., \& Karagüzel, R. (2010). Combining AHP with GIS for landfill site selection: A case study in the Lake Beys_ehircatchment area (Konya, Turkey), Waste Management, 30, 2037-2046.

Spierenburg, M. (2012). Getting the Message Across Biodiversity Science and Policy Interfaces - A Review GAIA 21/2: 125 -134.

Sukhdev, P. et al., (2012). Resourcing The Aichi Biodiversity Targets: A First Assessment Of The Resources Required For Implementing The Strategic Plan For Biodiversity 2011-2020 Report Of The High-Level Panel On Global Assessment Of Resources For Implementing The Strategic Plan For Biodiversity 2011-2020 UNEP/CBD/COP/11/INF/20.

Sutherland, W.J., Adams, W.M., Aronson, R. B., Aveling, R., Blackburn, T. M., Broad, S., Ceballos, G., Coté, I. M., Cowling, R.M., Da Fonseca, G.A.B., Dinerstein, E., Ferraro, P. J., Fleishman, E., Gascon, C., Hunter Jr.,M., Hutton, J., Kareiva, P., Kuria, A., Macdonald, D.W., Mackinnon, K., Madgwick, F. J., Mascia, M. B., Mcneely, J., Milner-Gulland, E.J., Moon, S., Morley, C.G., Nelson, S., Osborn, D., Pai, M., Parsons, E.C. M., Peck, L.S., Possingham, H., Prior, S.V., Pullin, A.S., Rands, M.R.W., Ranganathan, J., Redford, K.H., Rodriguez, J.P., Seymour, F., Sobel, J., Sodhi, N.S., Stott, A., Vance-Borland, K., \& Watkinson, A.R.. (2009). One Hundred Questions of Importance to the Conservation of Global Biological Diversity. Conservation Biology, Volume 23, No. 3, 557-567.

Tarimcilar, M.M., and Khaksari, S.Z., (1991). Capital-budgeting in hospital management using the Analytic Hierarchy Process, Socio-Economic Planning Sciences, vol. 25, 27-34.

Taylor, I.R. (1994). Barn owls: Predator-prey relationships and conservation. Cambridge: Cambridge University Press.

van Til, J.A., et al., (2008). The use of the analytic hierarchy process to aid decision making in acquired equinovarus deformity, Arch Phys Med Rehabil, vol. 89, 457-62.

Wise., M.G., \& Bettinger, P., 2008. Geographic Information Systems: Applications in Natural Resource Management. Oxford University Press, London, $2^{\text {nd }}$ edition. 